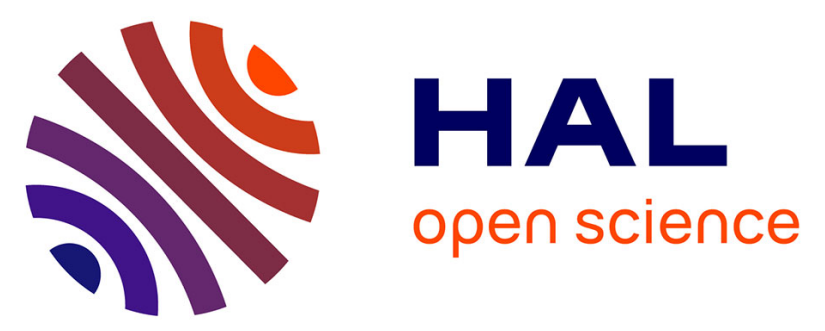

\title{
Management and Survival of Elderly and Very Elderly Patients with Endometrial Cancer: An Age-Stratified Study of 1228 Women from the FRANCOGYN Group
}

Clothilde Poupon, Sofiane Bendifallah, Lobna Ouldamer, Geoffroy Canlorbe, Emilie Raimond, Nina Hudry, Charles Coutant, Olivier Graesslin, Cyril Touboul, Pierre Collinet, et al.

\section{To cite this version:}

Clothilde Poupon, Sofiane Bendifallah, Lobna Ouldamer, Geoffroy Canlorbe, Emilie Raimond, et al.. Management and Survival of Elderly and Very Elderly Patients with Endometrial Cancer: An AgeStratified Study of 1228 Women from the FRANCOGYN Group. Annals of Surgical Oncology, 2017, 24 (6), pp.1667-1676. 10.1245/s10434-016-5735-9 . hal-01543370

\section{HAL Id: hal-01543370}

https://hal-univ-rennes1.archives-ouvertes.fr/hal-01543370

Submitted on 1 Sep 2017

HAL is a multi-disciplinary open access archive for the deposit and dissemination of scientific research documents, whether they are published or not. The documents may come from teaching and research institutions in France or abroad, or from public or private research centers.
L'archive ouverte pluridisciplinaire HAL, est destinée au dépôt et à la diffusion de documents scientifiques de niveau recherche, publiés ou non, émanant des établissements d'enseignement et de recherche français ou étrangers, des laboratoires publics ou privés. 
Management and survival of elderly and very elderly patients with endometrial cancer: an age-stratified study on 1228 women from the FRANCOGYN group

Clothilde Poupon ${ }^{1}$, Sofiane Bendifallah ${ }^{2,3}$, Lobna Ouldamer ${ }^{4}$, Geoffroy Canlorbe ${ }^{2}$, Emilie Raimond ${ }^{5}$, Nina Hudry ${ }^{6}$, Charles Coutant ${ }^{6}$, Olivier Graesslin ${ }^{5}$, Cyril Touboul ${ }^{7}$, Pierre Collinet ${ }^{8}$, Alexandre Bricou ${ }^{9}$, Cyrille Huchon $^{10}$, Emile Daraï ${ }^{2,11}$, Marcos Ballester ${ }^{2,11}$, Jean Levêque ${ }^{1}$, Vincent Lavoue ${ }^{1}$

1. CHU de Rennes, service de gynécologie, Hopital sud, 16 bd de Bulgarie, 35000 Rennes, FRANCE; Université de Rennes 1, France; ER440, Oncogenesis, Stress and Signaling, CRLCC Eugène Marquis, Rennes, France.

2. Department of Gynaecology and Obstetrics, Tenon University Hospital, Assistance Publique des Hôpitaux de Paris (AP-HP), University Pierre and Marie Curie, Paris 6, Institut Universitaire de Cancérologie (IUC), France.

3. INSERM UMR_S_707, "Epidemiology, Information Systems, Modeling", University Pierre and Marie Curie, Paris 6, France;

4. Department of Obstetrics and Gynaecology, Centre hospitalier régional universitaire de Tours, hôpital Bretonneau, Tours, France.

5. Department of Obstetrics and Gynaecology, Institute Alix de Champagne University Hospital, Reims, France.

6. Centre de lutte contre le cancer Georges François Leclerc, Dijon, France.

7. Department of Obstetrics and Gynaecology, Centre Hospitalier Intercommunal, Créteil, France.

8. Department of Obstetrics and Gynaecology, Centre Hospitalier Régional Universitaire, Lille, France.

9. Department of Gynaecology and Obstetrics, Jean Verdier University Hospital, Assistance Publique des Hôpitaux de Paris (AP-HP), University Paris 13, France.

10. Department of Gynaecology and Obstetrics, Centre Hospitalier Intercommunal, Poissy, France,

11. INSERM UMR_S_938, University Pierre et Marie Curie, Paris 6, France

Corresponding author: Pr Vincent Lavoué. vincent.lavoue@chu-rennes.fr. Service de gynécologie, CHU de Rennes, Hôpital Sud, 16 bd de Bulgarie 35000 Rennes, France. Tel: + 33299264321.

\section{Authors have no conflict of interest.}




\begin{abstract}
Introduction: Little data exist about the clinical management and survival of elderly patients with endometrial cancer. The aim of this study was to evaluate the management of elderly and very elderly patients with endometrial cancer and the overall survival (OS) rate, disease-free survival (DFS) rate and cancer-specific survival (CSS) rate within a multicentre cohort.

Material and methods: Data from 1228 patients with endometrial cancer who received primary treatment between January 2001 and December 2012 were collected from a multicentre database. Clinical management, DFS, CSS and OS were analysed.

Results: Based on the international endometrial cancer risk classification, 36\% (212/582) of women $\leq 65$ years, $42 \%(220 / 526)$ of women $>65$ years and $\leq 80$ years and $48 \%(58 / 120)$ of women $>80$ years showed high-risk endometrial cancer $(\mathrm{p}<0.001)$. Pelvic lymphadenectomy was performed in $85 \%(230 / 271)$ of women $\leq 65$ years and $46 \%(33 / 71)$ of women $>80$ years $(\mathrm{p}<0.001)$. Radiotherapy was performed in $27 \%(33 / 120)$ of very elderly and $40 \%(233 / 582)$ of young patients $(\mathrm{p}=0.009)$. The 3 -year CSS rates were $95 \%(95 \% \mathrm{CI}, 93-97), 90 \%(95 \%$ CI, 87-94) and $82 \%(95 \% \mathrm{CI}, 73-93)$ for women $\leq 65$ years, $>65$ and $\leq 80$ years, and $>80$ years, respectively $(\mathrm{p}<0.001)$.
\end{abstract}

Conclusions: Elderly and very elderly patients with endometrial cancer showed poorer prognosis than young patients. The significant lower CSS rate in elderly patients could be due to the higher rate of high-risk endometrial cancer but also due to under-treatment. Specific guidelines for the management of elderly and very elderly patients with endometrial cancer are needed to improve their prognosis. 


\section{Introduction}

As life expectancy continues to increase, the cohort of people over age of sixty-five accounts for almost twothirds of new cancer cases and three-fourths of cancer-related deaths ${ }^{1-3}$. Despite this trend, elderly patients have historically been under-represented in clinical trials ${ }^{4-7}$. Endometrial cancer is the most common gynaecologic malignancy in the western world, and in parallel to ageing demographics, incidence of endometrial cancer has been increasing: the average age of diagnosis is approximately 68 years ${ }^{8-10}$. It has been estimated that in the United States, more than 54,870 cases are diagnosed each year, and 10,170 deaths related to this malignancy occurred in $2015{ }^{11}$. The standard of care for endometrial cancer remains controversial, but it mostly includes comprehensive surgical staging as recommended by the International Federation of Gynecology and Obstetrics (FIGO) ${ }^{12}$. This can involve complex procedures such as pelvic and para-aortic lymphadenectomy and omentectomy, especially for high-risk endometrial cancer ${ }^{12-17}$, and the biological aggressiveness of endometrial cancer increases with age ${ }^{17-19}$. The benefit of applying these complex procedures to elderly patients remains unclear. Indeed, scarce data exist about overall survival and specific cancer-related death in the elderly and very elderly patients. In addition, available data are biased by the different definitions of "older age" and "elderly" used $^{20}$. Some authors consider older age to be over 65 years, whereas others use more strict parameters such as an age $\geq 75$ or $\geq 80$ years ${ }^{21}$.

The aim of this study was to evaluate the management of elderly and very elderly patients with endometrial cancer and their disease-free survival, overall survival, and cancer-specific survival rates within a large French multicentre cohort. 


\section{Material and methods}

\section{Patients}

Data on women with histologically proven endometrial cancer who received primary surgical treatment between January 2001 and December 2013 were abstracted from seven institutions in France with maintained endometrial cancer databases (Tours University Hospital, Tenon University Hospital, Dijon Cancer Centre, Rennes University Hospital, Lille University Hospital, Reims University Hospital, Creteil University Hospital and Jean Verdier University Hospital) and from the Senti-Endo trial ${ }^{22}$. The research protocol was approved by the Institutional Review Board of the College National des Gynécologues et Obstétriciens Français (CEROG 2014-GYN-020).

All enrolled women underwent preoperative abdomino-pelvic magnetic resonance imaging (MRI) unless contraindicated, in which case a computed tomography (CT) scan was performed. The following clinical, surgical and pathological data were collected: age; body mass index (BMI; calculated as weight in kilograms divided by the square of height in metres), surgical procedure, nodal staging and adjuvant therapy.

The patients were divided into three cohorts: 1) women $\leq 65$ years old, 2) women $>65$ years old and $\leq 80$ years old, and 3) women >80 years old, which were designated as young, elderly and very elderly patients, respectively.

\section{Histology}

Lymph nodes (LN) were considered positive when there were macro- and/or micrometastases. Macrometastases were defined as a single focus of metastatic disease per LN, measuring more than $2 \mathrm{~mm}$. Micrometastases were defined as a single focus of metastatic disease per LN, measuring between 0.2 and $2 \mathrm{~mm}$ 23. A tumour is considered to have lymphovascular space involvement (LVSI) when tumour emboli are found within a space clearly lined by endothelial cells on a haematoxylin and eosin (H\&E)-stained section ${ }^{24}$. Type 1 tumours consisted of endometrioid adenocarcinomas and mixed tumours with a mucinous, villoglandular or tubular component in addition to the endometrioid component. For these tumours, histological grade was defined by the percentage of the undifferentiated component: grade 1 corresponded to an undifferentiated component less than 5\%, grade 2 from $6 \%$ to $50 \%$ and grade 3 more than $50 \%$. When nuclear atypia was present, the grade was increased by 1 point ${ }^{25}$.

Type 2 tumours were those with at least one serous, clear cell or carcinosarcoma component.

All women were classified according to the FIGO 2009 classification ${ }^{26}$ after final pathological analysis. 
The tumours were classified into recurrence risk groups as defined by the European Society for Medical Oncology (ESMO) / European Society of Gynaecological Oncology (ESGO) / European Society for Radiotherapy and Oncology (ESTRO) guidelines ${ }^{13}$. The four risks groups were determined as follows: low risk - stage IA, grade 1 or 2 , histological type 1 ; intermediate risk - stage IA, grade 3 and stage IB, grade 1 or 2 , histological type 1; high intermediate risk (HIR) subgroup, defined as endometrioid type 1, grade 1-2 tumours with deep ( $\geq 50 \%$ ) myometrial invasion and unequivocally positive (substantial, not focal) LVSI and those with grade 3 tumours with $<50 \%$ myometrial invasion regardless of LVSI status; and high risk - stage IB, grade 3 and, by extension, stage $\geq \mathrm{II}$, histological type 1 , as well as all type 2 tumours of any stage.

\section{Treatment and follow-up}

According to INCa guidelines, pelvic and paraaortic lymph node surgical staging is required for HIR and high-risk groups, and pelvic lymph node surgical staging is required for intermediate-risk groups. Adjuvant therapy was administered on an individual basis at the discretion of a multidisciplinary committee, based on the INCa guidelines, and included vaginal brachytherapy (VBT) and/or external beam radiotherapy (EBRT) and/or chemotherapy (CT) and clinical follow-up [27]. Chemotherapy performed were four cycles of carboplatin and taxol. Clinical follow-up consisted of physical examinations and the use of imaging techniques according to the findings. Follow-up visits were conducted every 3 months for the first 2 years, every 6 months for the following 3 years, and once a year thereafter. Disease recurrence was diagnosed by biopsy or imaging.

\section{Outcome measures}

The primary outcome measures were date of recurrence, date of death and date of cancer-related death. The secondary outcome measures were surgical staging compliance with French national guidelines [25] and surgical route (minimally invasive surgery, laparotomy and vaginal surgery).

\section{Statistical analysis}

Descriptive parameters were expressed as the mean ( \pm Standard Deviation $[\mathrm{SD}])$ and median [range] when indicated. Frequencies were presented as percentages. We used Chi-square or Fisher's exact tests, as appropriate, for categorical or ordinal variables. For continuous variables, we used $t$-tests when there were two variables to compare or one-way ANOVA when there were more than 2 variables. Overall survival time was calculated in months from the date of surgery to death (related or unrelated to cancer) or date of last follow-up for surviving patients; cancer-specific survival (CSS) was calculated as time from the date of surgery to cancerrelated death; and disease-free survival (DFS) was time from the date of surgery to cancer recurrence. Women who were alive and without recurrence were censored at the date of last follow-up. The Kaplan-Meier method 
was used to estimate the survival distribution. Tick marks indicate censored data. The comparison test chosen to analyse survival was the log-rank test. Effects were expressed as hazard ratios (HRs) with $95 \%$ confidence intervals (CIs) as appropriate. Cox proportional hazard models included established prognostic factors: pathological type, adjuvant therapies, and nodal and LVSI status. A p-value of $<0.05$ was considered statistically significant. Data were managed in an Excel database (Microsoft, Redmond, WA, USA) and analysed using R 3.0.2 software, which is available online. 


\section{Results:}

\section{Characteristics of the study population}

During the study period, 1228 women with endometrial cancer were documented as having received primary surgical treatment according to the following distribution. According to the three age groups, 582 (47\%), $526(43 \%)$ and $120(10 \%)$ women were $\leq 65$ years old, $>65$ years old and $\leq 80$ years old, and $>80$ years old, respectively.

The median age of the women was 66.0 years (range 28-88 years), and their median BMI was $28.0 \mathrm{~kg} / \mathrm{m}^{2}$ (range 14.0-52.7). The demographic and clinicopathological characteristics of the whole cohort by age group are reported in Table 1. The rate of comorbidities, such as diabetes, high blood pressure, and previous breast cancer, was significantly higher in the older age groups.

\section{Tumour characteristics}

The tumour characteristics are reported in table 2 . Of note, elderly and very elderly women experienced more endometrial cancers with biological parameters indicating a poor prognosis. Indeed, 55\% (58/106) of very elderly patients had a positive LVSI status vs 29\% $(148 / 516)$ of young patients $(\mathrm{p}<0.001)$. Similarly, $48 \%$ (58/120) of very elderly patients showed high-risk endometrial cancer vs 37\% (212/582) of young patients $(p=0.003)$.

\section{Surgical procedures and adjuvant treatment}

The surgical procedures are described in table 3. Very elderly patients had less laparoscopic surgery than young patients: $50 \%(56 / 112)$ vs 62\% (314/508), $(\mathrm{p}=0.015)$, respectively. Additionally, 59\% (71/120) of very elderly women required pelvic \pm para-aortic lymphadenectomy according to French guidelines, whereas this rate was $47 \%(271 / 582)$ in young women $(\mathrm{p}=0.011)$. However, pelvic \pm para-aortic lymphadenectomy was performed for $46 \%(33 / 71)$ of very elderly patients and $85 \%(230 / 271)$ of young patients $(\mathrm{p}<0.001)$.

The adjuvant treatments are reported in table 3 . Radiotherapy was performed in $28 \%(33 / 120)$ of very elderly and $40 \%(233 / 582)$ of young patients $(\mathrm{p}=0.008)$. Chemotherapy was performed in $4 \%(5 / 120)$ of very elderly and $19 \%(113 / 582)$ of young patients $(\mathrm{p}<0.001)$. Additionally, $50 \%(60 / 120)$ of very elderly and $35 \%(230 / 582)$ of young patients with endometrial cancer required radiotherapy according to French guidelines $(p=0.003)$, but radiotherapy was performed in 55\% (33/60) of very elderly women and $85 \%(201 / 230)$ of young patients $(\mathrm{p}=0.013)$. Among very elderly women, 40\% (48/120) required chemotherapy according to French guidelines $v s$ $30 \%(172 / 582)$ of young women with endometrial cancer $(\mathrm{p}=0.044)$, but chemotherapy was performed in $10 \%$ $(5 / 48)$ of very elderly women and $56 \%(96 / 172)$ of young patients $(\mathrm{p}<0.001)$. 


\section{Survival results}

In the whole cohort, the mean time of follow-up was $34.9( \pm 30.2)$ months, respectively. In the whole population, recurrences were observed in 240 of the 1228 women (19.5\%). The median and mean time of recurrence were 27 [1-386] and $37.7( \pm 36.2)$ months, respectively. In the whole population, the respective 5-year OS and DFS were 80.7\% (95\% CI, 77.2-84.4) and 75.7 (95\% CI, 72.4-79.3\%), respectively.

The survival curves are shown in figure 1. The cancer-specific survival was significantly lower in elderly and very elderly patients $(\mathrm{p}<0.001)$ (figure 1$)$. The three-year DFS, CSS and OS rates are shown in table S1 (Supplementary data, table S1) (univariate analysis) and table 4 (multivariate analysis). 


\section{Discussion}

Present study highlights the occurrence of more aggressive endometrial cancer in elderly ( $>65$ years) and very elderly (>80 years) patients when compared with younger patients ${ }^{27}$. Despite more aggressive histology (higher rate of type 2 cancer or LVSI), elderly and very elderly women had significantly less surgical staging (less lymphadenectomy) and less adjuvant radio- or chemotherapy, even when adjuvant treatment was required by guidelines according to tumour status. Data from the follow-up highlight the fact that CSS was significantly lower in elderly and very elderly women compared with their younger counterparts. Thus, this higher rate of cancer related mortality could be due to the occurrence of more aggressive endometrial cancer in elderly women but also to under-treatment. The three-year OS rate was lower than the CSS rate, indicating that death was due to cancer but also to causes other than cancer. Thus, the joint causes of death in the elderly indicate that standard treatments should be performed in some elderly patients but that the entire group of elderly patients would not benefit from this standard treatment, as some of them die from causes other than cancer. Our study emphasizes the urgent need for specific guidelines for elderly and very elderly patients with endometrial cancer.

Physicians have to consider which surgical staging to perform in elderly and very elderly women, especially for lymph node dissection associated with hysterectomy. Although minimally invasive surgery is feasible in the elderly and has shown fewer complications than laparotomy [33], major complications, grade III and IV according to the Clavien-Dindo classification [34], remain higher in patients $>70$ years old ${ }^{17}$. The performance of lymph node dissection increases the surgery length and the rate of complications, particularly in the elderly ${ }^{28,29}$. Nevertheless, known lymph node status remains crucial to tailoring adjuvant treatment, especially in highrisk endometrial cancer, which occurs more frequently in the elderly ${ }^{30,31}$. Sentinel lymph node biopsy could resolve the question of node status in endometrial cancer because it addresses lymph node involvement with less morbidity ${ }^{22,32,33}$. Unfortunately, our results showed that sentinel lymph node biopsy was used less often in elderly and very elderly patients, despite their poorer prognosis endometrial cancer.

The choice of adjuvant treatment depends on the cancer prognosis but also on life expectancy, especially in elderly and very elderly patients. In the present study, as others, we showed that elderly and very elderly women received significantly less adjuvant chemo- and radiotherapy than younger patients, despite their higher rate of high-risk endometrial cancer ${ }^{34-36}$. The Post Operative Radiation Therapy in Endometrial Carcinoma (PORTEC) 1 trial showed that women over the age of 60 were threefold more likely to have a locoregional recurrence following radical surgery compared to younger patients (HR $3.90 \mathrm{p}=0.0017){ }^{37}$. The local recurrence rate in the PORTEC 1 study population was reduced from $15.5 \%$ to $6.0 \%$ with the addition of post-operative external beam 
radiotherapy (EBRT). Of note, in present study, elderly had significantly less EBRT. Although, there was no significant difference in late radiation toxicity between patients aged $\leq 64,65-74$ and $\geq 75$ years old ${ }^{38}$.

One of the limitations of the present study was its retrospective nature, which led to missing data; however, the present cohort was very large, one of the most important published to date ${ }^{19}$, and the patients were managed in tertiary centers, which used well documented electronic charts. Secondly, the median follow-up for recurrence was relatively short. However, the majority of recurrences $(74 \% ; 63 / 85)$ occurred during the 2 years of followup. In addition, our median time of follow-up is consistent with previous studies evaluating the prognosis of endometrial cancer ${ }^{39,40}$. Thirdly, during the data collection period, there were changes in staging modalities (FIGO classification) ${ }^{26}$ and in the indications for nodal staging and adjuvant therapies. For example, para-aortic lymph node dissection was not systematically recommended in France for high-risk patients before 2010. In the same way, in a recent pooled analysis of the PORTEC-1 and -2 trials on the clinical impact of LVSI, the authors report that substantial LVSI remains the strongest independent prognostic factor for pelvic regional recurrence, distant metastasis and OS ${ }^{15,16}$. Hence, for unstaged women, EBRT is recommended for unequivocally positive LVSI to reduce pelvic recurrence, by ESMO/ESGO/ESTRO ${ }^{41}$. In the same way, chemotherapy is now recommended for high-risk endometrial cancer. We noted less adjuvant treatment in elderly and very elderly, but younger counterpart did always not have optimal treatment, especially in high-risk endometrial cancer, because of these recommendation changes. Besides, during the data collection period, perception of aging changed in the oncology field, the concept of frailty was introduced to assess therapeutic morbidity risk ${ }^{42-44}$. The lower rate of lymph node dissection in the elderly and very elderly patients could have been due to a discrepancy between preand postoperative risk groups in whom lymph node dissection was not systematically recommended, mainly due to the associated morbidities ${ }^{45}$. Lastly, no attempt was made to replace numerical age by criteria evaluating life expectancy. Defining elderly patients based on functional status using geriatric evaluation tools might have been more discriminatory than age alone ${ }^{46}$. Some validated tools exist to predict frailty ${ }^{47}$ and toxicity from chemotherapy ${ }^{43,44,47}$, but not for oncologic surgery and chronological age remains a crucial determinant of treatment decisions ${ }^{48,49}$.

\section{Conclusion}

Our large cohort study highlights the worse prognosis of endometrial cancer in elderly and very elderly patients when compared with their younger counterparts. Despite the significantly higher rate of high-risk endometrial cancer in the elderly, the rates of lymph node dissection and adjuvant therapy were significantly lower. The 
significantly lower CSS rate in these elderly populations could have been due to their higher rate of high-risk endometrial cancer but also to under-treatment.

\section{Acknowledgements:}

Authors thank American Journal Expert for the editing of the manuscript. There is no funding source.

\section{Conflict of interest statement:}

Authors have no conflict of interest. 


\section{References}

1. Reis L, Eisner M, Kosary C, et al. SEER Cancer Statistics Review, 1975-2000, National Cancer Institute. Bethesda. 2003.

2. U.S. Census Bureau (2000) The 65 years and over population: 2000. Available at: http://www.census.gov/prod/2001 pubs/c2kbr01-10.pdf. Internet release date: October 2001.

3. Stein JP, Lieskovsky G, Cote R, et al. Radical cystectomy in the treatment of invasive bladder cancer: long-term results in 1,054 patients. J Clin Oncol 2001;19:666-75.

4. Lewis JH, Kilgore ML, Goldman DP, et al. Participation of patients 65 years of age or older in cancer clinical trials. J Clin Oncol 2003;21:1383-9.

5. Hutchins LF, Unger JM, Crowley JJ, Coltman CA, Jr., Albain KS. Underrepresentation of patients 65 years of age or older in cancer-treatment trials. N Engl J Med 1999;341:2061-7.

6. Yee KW, Pater JL, Pho L, Zee B, Siu LL. Enrollment of older patients in cancer treatment trials in Canada: why is age a barrier? J Clin Oncol 2003;21:1618-23.

7. Trimble EL, Carter CL, Cain D, Freidlin B, Ungerleider RS, Friedman MA. Representation of older patients in cancer treatment trials. Cancer 1994;74:2208-14.

8. Edwards BK, Howe HL, Ries LA, et al. Annual report to the nation on the status of cancer, 1973-1999, featuring implications of age and aging on U.S. cancer burden. Cancer 2002;94:2766-92.

9. Yancik R, Ries LA. Cancer in older persons: an international issue in an aging world. Semin Oncol 2004;31:128-36.

10. Siegel R, Ward E, Brawley O, Jemal A. Cancer statistics, 2011: the impact of eliminating socioeconomic and racial disparities on premature cancer deaths. CA Cancer J Clin 2011;61:212-36.

11. Siegel R, Miller KD, Jemal A. Cancer statistics. CA Cancer J Clin 2015;65:5-29.

12. Mikuta JJ. International Federation of Gynecology and Obstetrics staging of endometrial cancer 1988. Cancer 1993;71:1460-3.

13. Colombo N, Preti E, Landoni F, et al. Endometrial cancer: ESMO Clinical Practice Guidelines for diagnosis, treatment and follow-up. Ann Oncol 2013;24 Suppl 6:vi33-8.

14. Bendifallah S, Canlorbe G, Collinet P, et al. Just how accurate are the major risk stratification systems for early-stage endometrial cancer? Br J Cancer 2015;112:793-801.

15. Group SGOCPECW, Burke WM, Orr J, et al. Endometrial cancer: a review and current management strategies: part II. Gynecol Oncol 2014;134:393-402.

16. Group SGOCPECW, Burke WM, Orr J, et al. Endometrial cancer: a review and current management strategies: part I. Gynecol Oncol 2014;134:385-92.

17. Zeng XZ, Lavoue V, Lau S, et al. Outcome of robotic surgery for endometrial cancer as a function of patient age. Int J Gynecol Cancer 2015;25:637-44.

18. Setiawan VW, Yang HP, Pike MC, et al. Type I and II endometrial cancers: have they different risk factors? J Clin Oncol 2013;31:2607-18.

19. Uccella S, Bonzini M, Palomba S, et al. Laparoscopic vs. open treatment of endometrial cancer in the elderly and very elderly: An age-stratified multicenter study on 1606 women. Gynecol Oncol 2016;141:211-7.

20. Scribner DR, Jr., Walker JL, Johnson GA, McMeekin SD, Gold MA, Mannel RS. Surgical management of early-stage endometrial cancer in the elderly: is laparoscopy feasible? Gynecol Oncol 2001;83:563-8.

21. Oresanya LB, Lyons WL, Finlayson E. Preoperative assessment of the older patient: a narrative review. JAMA 2014;311:2110-20.

22. Ballester M, Dubernard G, Lecuru F, et al. Detection rate and diagnostic accuracy of sentinel-node biopsy in early stage endometrial cancer: a prospective multicentre study (SENTI-ENDO). Lancet Oncol 2011;12:469-76.

23. Singletary SE, Allred C, Ashley P, et al. Revision of the American Joint Committee on Cancer staging system for breast cancer. J Clin Oncol 2002;20:3628-36.

24. Briet JM, Hollema H, Reesink N, et al. Lymphvascular space involvement: an independent prognostic factor in endometrial cancer. Gynecol Oncol 2005;96:799-804.

25. Querleu D, Planchamp F, Narducci F, et al. Clinical practice guidelines for the management of patients with endometrial cancer in France: recommendations of the Institut National du Cancer and the Societe Francaise d'Oncologie Gynecologique. Int J Gynecol Cancer 2011;21:945-50.

26. Pecorelli S. Revised FIGO staging for carcinoma of the vulva, cervix, and endometrium. Int J Gynaecol Obstet 2009;105:103-4.

27. Bourgin C, Saidani M, Poupon C, et al. Endometrial cancer in elderly women: Which disease, which surgical management? A systematic review of the literature. Eur J Surg Oncol 2016;42:166-75.

28. De Marzi P, Ottolina J, Mangili G, et al. Surgical treatment of elderly patients with endometrial cancer (>/= 65 years). J Geriatr Oncol 2013;4:368-73. 
29. Turrentine FE, Wang H, Simpson VB, Jones RS. Surgical risk factors, morbidity, and mortality in elderly patients. J Am Coll Surg 2006;203:865-77.

30. Morice P, Leary A, Creutzberg C, Abu-Rustum N, Darai E. Endometrial cancer. Lancet 2016;387:1094108.

31. Koskas M, Rouzier R, Amant F. Staging for endometrial cancer: The controversy around lymphadenectomy - Can this be resolved? Best Pract Res Clin Obstet Gynaecol 2015;29:845-57.

32. Raimond E, Ballester M, Hudry D, et al. Impact of sentinel lymph node biopsy on the therapeutic management of early-stage endometrial cancer: Results of a retrospective multicenter study. Gynecol Oncol 2014;133:506-11.

33. Kang S, Yoo HJ, Hwang JH, Lim MC, Seo SS, Park SY. Sentinel lymph node biopsy in endometrial cancer: meta-analysis of 26 studies. Gynecol Oncol 2011;123:522-7.

34. Clark LH, Jackson AL, Gehrig PA, Bae-Jump V, Van Le L, Ko EM. Adjuvant Treatment and Clinical Trials in Elderly Patients With Endometrial Cancer: A Time for Change? Int J Gynecol Cancer 2016;26:282-9.

35. Truong PT, Kader HA, Lacy B, et al. The effects of age and comorbidity on treatment and outcomes in women with endometrial cancer. Am J Clin Oncol 2005;28:157-64.

36. Rauh-Hain JA, Pepin KJ, Meyer LA, et al. Management for Elderly Women With Advanced-Stage, High-Grade Endometrial Cancer. Obstet Gynecol 2015;126:1198-206.

37. Magne N, Mancy NC, Chajon E, et al. Patterns of care and outcome in elderly cervical cancer patients: a special focus on brachytherapy. Radiother Oncol 2009;91:197-201.

38. Ikushima H, Takegawa Y, Osaki K, et al. Radiation therapy for cervical cancer in the elderly. Gynecol Oncol 2007; 107:339-43.

39. Hamilton CA, Cheung MK, Osann K, et al. Uterine papillary serous and clear cell carcinomas predict for poorer survival compared to grade 3 endometrioid corpus cancers. Br J Cancer 2006;94:642-6.

40. Greggi S, Mangili G, Scaffa C, et al. Uterine papillary serous, clear cell, and poorly differentiated endometrioid carcinomas: a comparative study. Int J Gynecol Cancer 2011;21:661-7.

41. Bosse T, Peters EE, Creutzberg CL, et al. Substantial lymph-vascular space invasion (LVSI) is a significant risk factor for recurrence in endometrial cancer--A pooled analysis of PORTEC 1 and 2 trials. Eur J Cancer 2015;51:1742-50.

42. Robinson TN, Eiseman B, Wallace JI, et al. Redefining geriatric preoperative assessment using frailty, disability and co-morbidity. Ann Surg 2009;250:449-55.

43. Hurria A, Togawa K, Mohile SG, et al. Predicting chemotherapy toxicity in older adults with cancer: a prospective multicenter study. J Clin Oncol 2011;29:3457-65.

44. Hurria A, Mohile S, Gajra A, et al. Validation of a Prediction Tool for Chemotherapy Toxicity in Older Adults With Cancer. J Clin Oncol 2016;34:2366-71.

45. Achouri A, Huchon C, Bats AS, Bensaid C, Nos C, Lecuru F. Complications of lymphadenectomy for gynecologic cancer. Eur J Surg Oncol 2013;39:81-6.

46. Afilalo J, Eisenberg MJ, Morin JF, et al. Gait speed as an incremental predictor of mortality and major morbidity in elderly patients undergoing cardiac surgery. J Am Coll Cardiol 2010;56:1668-76.

47. Extermann M, Boler I, Reich RR, et al. Predicting the risk of chemotherapy toxicity in older patients: the Chemotherapy Risk Assessment Scale for High-Age Patients (CRASH) score. Cancer 2012;118:3377-86.

48. Dumas L, Ring A, Butler J, Kalsi T, Harari D, Banerjee S. Improving outcomes for older women with gynaecological malignancies. Cancer Treat Rev 2016;50:99-108.

49. Huisman MG, Kok M, de Bock GH, van Leeuwen BL. Delivering tailored surgery to older cancer patients: Preoperative geriatric assessment domains and screening tools - A systematic review of systematic reviews. EJSO 2016; Epub ahead of print. 
Figure 1: Survival curves: Disease-free survival (A), Cancer-specific survival (B), Overall survival (C)

A

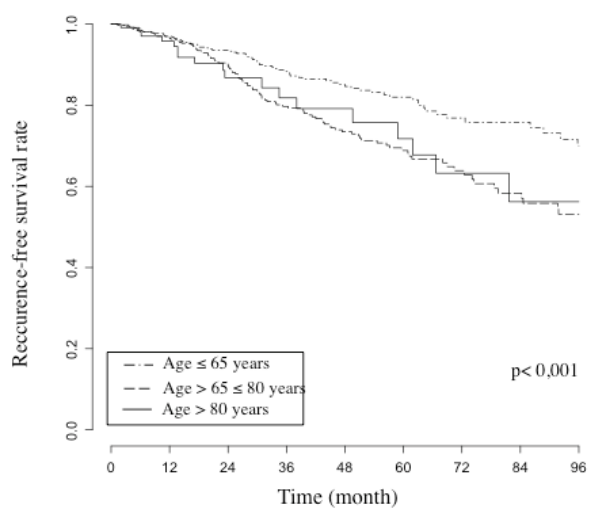

B

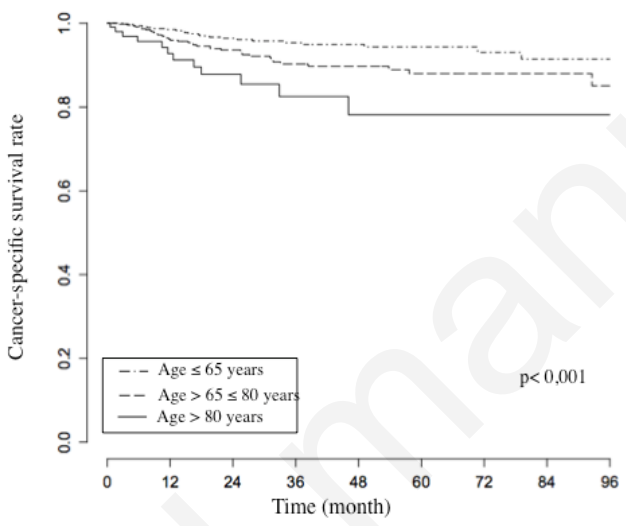

C

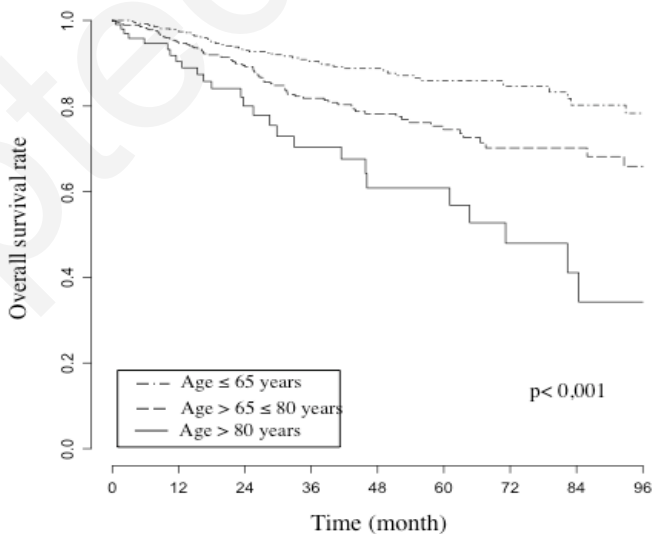


Table 1: Patient characteristics

\begin{tabular}{|c|c|c|c|c|c|}
\hline Characteristics & $\begin{array}{c}\text { Population } \\
\text { n }(\%) \\
\mathrm{N}=\mathbf{1 2 2 8}\end{array}$ & $\begin{array}{c}\text { Age } \leq \mathbf{6 5} \text { years } \\
\mathbf{n}(\%) \\
\mathbf{N}=\mathbf{5 8 2}\end{array}$ & $\begin{array}{c}65 \text { years }<\text { Age } \leq 80 \text { years } \\
\text { n }(\%) \\
\mathbf{N}=526\end{array}$ & $\begin{array}{c}\text { Age }>80 \text { years } \\
\text { n }(\%) \\
\mathbf{N}=120\end{array}$ & $\begin{array}{c}P \\
\text { value }\end{array}$ \\
\hline Age (years), mean $( \pm \mathrm{SD})$ & $66( \pm 0.6)$ & $57( \pm 0.5)$ & $72.2( \pm 0.3)$ & $83,9( \pm 0.6)$ & $<0.001$ \\
\hline BMI $(\mathrm{kg} / \mathrm{m} 2)$, mean $( \pm \mathrm{SD})$ & $29.5( \pm 0.4)$ & $30.30( \pm 0.7)$ & $29.2( \pm 0.6)$ & $26.6( \pm 1.0)$ & 0.003 \\
\hline \multicolumn{6}{|l|}{ Parity } \\
\hline $\begin{array}{l}-0 \\
-1 \\
-\geq 2 \\
-\mathrm{NC}\end{array}$ & $\begin{array}{l}137(11 \%) \\
190(15 \%) \\
537(44 \%) \\
364(30 \%)\end{array}$ & $\begin{array}{l}83(14 \%) \\
80(14 \%) \\
239(41 \%) \\
179(31 \%)\end{array}$ & $\begin{array}{l}37(7 \%) \\
89(17 \%) \\
243(46 \%) \\
157(30 \%)\end{array}$ & $\begin{array}{l}17(14 \%) \\
20(17 \%) \\
55(46 \%) \\
28(23 \%)\end{array}$ & 0.002 \\
\hline $\begin{array}{l}\text { Menopause } \\
\text { - Yes } \\
\text { - No } \\
\text { - NC } \\
\text { Arterial hypertension }\end{array}$ & $\begin{array}{c}964(78 \%) \\
93(8 \%) \\
171(14 \%)\end{array}$ & $\begin{array}{l}397(68 \%) \\
93(16 \%) \\
92(16 \%)\end{array}$ & $\begin{array}{c}526(100 \%) \\
0(0 \%) \\
0(0 \%)\end{array}$ & $\begin{array}{c}120(100 \%) \\
0(0 \%) \\
0(0 \%)\end{array}$ & $<0.001$ \\
\hline $\begin{array}{l}\text { - Yes } \\
\text { - No } \\
\text { - NC }\end{array}$ & $\begin{array}{l}434(35 \%) \\
495(40 \%) \\
299(25 \%)\end{array}$ & $\begin{array}{l}151(26 \%) \\
278(48 \%) \\
153(26 \%)\end{array}$ & $\begin{array}{l}218(41 \%) \\
183(35 \%) \\
125(24 \%)\end{array}$ & $\begin{array}{l}65(54 \%) \\
34(28 \%) \\
21(18 \%)\end{array}$ & $<0.001$ \\
\hline \multicolumn{6}{|l|}{ Diabetes } \\
\hline $\begin{array}{l}\text { - Yes } \\
\text { - No } \\
\text { - NC }\end{array}$ & $\begin{array}{l}186(15 \%) \\
891(73 \%) \\
151(12 \%)\end{array}$ & $\begin{array}{l}87(15 \%) \\
422(73 \%) \\
73(12 \%)\end{array}$ & $\begin{array}{l}75(14 \%) \\
381(73 \%) \\
70(13 \%)\end{array}$ & $\begin{array}{c}24(20 \%) \\
88(73 \%) \\
8(7 \%)\end{array}$ & 0.453 \\
\hline \multicolumn{6}{|l|}{$\begin{array}{l}\text { Menopausal hormone } \\
\text { therapy }\end{array}$} \\
\hline $\begin{array}{l}\text { - Yes } \\
\text { - No } \\
\text { - NC }\end{array}$ & $\begin{array}{l}180(15 \%) \\
591(48 \%) \\
457(37 \%)\end{array}$ & $\begin{array}{l}76(13 \%) \\
293(50 \%) \\
213(37 \%)\end{array}$ & $\begin{array}{l}99(19 \%) \\
231(44 \%) \\
196(37 \%)\end{array}$ & $\begin{array}{c}5(4 \%) \\
67(56 \%) \\
48(40 \%)\end{array}$ & $<0.001$ \\
\hline $\begin{array}{l}\text { Beast cancer antecedent } \\
\text { - Yes } \\
\text { - No } \\
\text { - NC }\end{array}$ & $\begin{array}{c}85(7 \%) \\
723(59 \%) \\
420(34 \%)\end{array}$ & $\begin{array}{c}29(5 \%) \\
343(59 \%) \\
210(36 \%)\end{array}$ & $\begin{array}{c}44(8 \%) \\
306(58 \%) \\
176(34 \%)\end{array}$ & $\begin{array}{l}12(10 \%) \\
74(62 \%) \\
34(28 \%)\end{array}$ & 0.062 \\
\hline
\end{tabular}

NC: not communicated 
Table 2: Tumour characteristics

\begin{tabular}{|c|c|c|c|c|c|}
\hline Characteristics & $\begin{array}{c}\text { Population } \\
\text { n }(\%) \\
\mathrm{N}=\mathbf{1 2 2 8}\end{array}$ & $\begin{array}{c}\text { Age } \leq \mathbf{6 5} \text { years } \\
\mathbf{n}(\%) \\
\mathbf{N}=\mathbf{5 8 2}\end{array}$ & $\begin{array}{c}65 \text { years }<\text { Age } \leq 80 \text { years } \\
\text { n }(\%) \\
\mathbf{N}=\mathbf{5 2 6}\end{array}$ & $\begin{array}{c}\text { Age }>\text { 80 years } \\
\text { n }(\%) \\
\mathbf{N}=120\end{array}$ & $\begin{array}{c}P \\
\text { value }\end{array}$ \\
\hline \multicolumn{6}{|l|}{ Tumour size } \\
\hline$-\geq 3,5 \mathrm{~cm}$ & $383(31 \%)$ & $172(30 \%)$ & $168(32 \%)$ & $43(36 \%)$ & \\
\hline$-\mathrm{NC}$ & $441(36 \%)$ & $211(36 \%)$ & $185(35 \%)$ & $45(38 \%)$ & NS \\
\hline \multicolumn{6}{|l|}{ Myometrial invasion } \\
\hline$-\geq 50 \%$ & $500(41 \%)$ & $199(34 \%)$ & $243(46 \%)$ & $58(48 \%)$ & \\
\hline$-\mathrm{NC}$ & $121(10 \%)$ & $59(10 \%)$ & $50(10 \%)$ & $12(10 \%)$ & $<0.001$ \\
\hline \multicolumn{6}{|l|}{ Histology } \\
\hline - Endometrioid & $946(77 \%)$ & $476(81 \%)$ & $383(73 \%)$ & $87(73 \%)$ & \\
\hline - Serous & $92(8 \%)$ & $35(6 \%)$ & $50(10 \%)$ & $7(6 \%)$ & \\
\hline - Clear cells & $66(5 \%)$ & $28(5 \%)$ & $34(6 \%)$ & $4(3 \%)$ & \\
\hline - Type 2 & $222(18 \%)$ & $83(14 \%)$ & $115(22 \%)$ & $24(20 \%)$ & \\
\hline - Other** & $7(1 \%)$ & $2(0 \%)$ & $4(0,5 \%)$ & $1(1 \%)$ & \\
\hline$-\mathrm{NC}$ & $18(1 \%)$ & $9(2 \%)$ & $4(0,5 \%)$ & $5(4 \%)$ & 0.003 \\
\hline \multicolumn{6}{|l|}{ Histological grade } \\
\hline-1 & $529(43 \%)$ & $277(48 \%)$ & $206(39 \%)$ & $46(38 \%)$ & \\
\hline-2 & $344(28 \%)$ & $156(27 \%)$ & $154(29 \%)$ & $34(29 \%)$ & \\
\hline-3 & $322(26 \%)$ & $134(23 \%)$ & $152(29 \%)$ & $36(30 \%)$ & \\
\hline - NC & $33(3 \%)$ & $15(2 \%)$ & $14(3 \%)$ & $4(3 \%)$ & 0.037 \\
\hline \multicolumn{6}{|l|}{$\begin{array}{l}\text { Lymphovascular space } \\
\text { involvement }\end{array}$} \\
\hline - Yes & $360(29 \%)$ & $148(26 \%)$ & $172(33 \%)$ & $40(33 \%)$ & \\
\hline \multicolumn{6}{|l|}{$\begin{array}{l}\text { Para-aortic lymph node } \\
\text { metastasis }\end{array}$} \\
\hline - Yes & $34(26 \%)$ & $20(25 \%)$ & $13(28 \%)$ & $1(33 \%)$ & \\
\hline - No & $81(63 \%)$ & $51(64 \%)$ & $29(63 \%)$ & $1(33 \%)$ & \\
\hline - NC & $14(11 \%)$ & $9(11 \%)$ & $4(9 \%)$ & $1(33 \%)$ & NS \\
\hline \multicolumn{6}{|l|}{ FIGO stage } \\
\hline - I & $856(70 \%)$ & $413(71 \%)$ & $361(69 \%)$ & $82(68 \%)$ & \\
\hline - II & $99(8 \%)$ & $40(7 \%)$ & $45(9 \%)$ & $14(12 \%)$ & \\
\hline - III & $243(20 \%)$ & $115(20 \%)$ & $107(20 \%)$ & $21(18 \%)$ & \\
\hline - IV & $30(2 \%)$ & $14(2 \%)$ & $13(2 \%)$ & $3(2 \%)$ & NS \\
\hline \multicolumn{6}{|c|}{$\begin{array}{l}\text { ESMO/ESGO/ESTRO risk } \\
\text { groups }\end{array}$} \\
\hline - Low risk & $399(33 \%)$ & $225(39 \%)$ & $142(27 \%)$ & $35(29 \%)$ & \\
\hline - Intermediate risk & $155(13 \%)$ & $63(11 \%)$ & $80(15 \%)$ & $12(10 \%)$ & \\
\hline - High-intermediate risk & $120(10 \%)$ & $54(9 \%)$ & $56(11 \%)$ & $10(8 \%)$ & \\
\hline - High risk & $495(40 \%)$ & $215(37 \%)$ & $222(42 \%)$ & $58(48 \%)$ & \\
\hline - Advanced/metastatic & $30(2 \%)$ & $14(2 \%)$ & $13(2,5 \%)$ & $3(2 \%)$ & \\
\hline$-\mathrm{NC}$ & $29(2 \%)$ & $11(2 \%)$ & $13(2,5 \%)$ & $5(4 \%)$ & 0.003 \\
\hline
\end{tabular}

$*$ mucinous, carcinosarcoma or undifferentiated, sex cord-stromal tumour, choriocarcinoma $* *$ sex cord-stromal tumour, choriocarcinoma

$$
\text { NC: not communicated; NS: not significant }
$$


Table 3: Surgical characteristics and adjuvant treatment

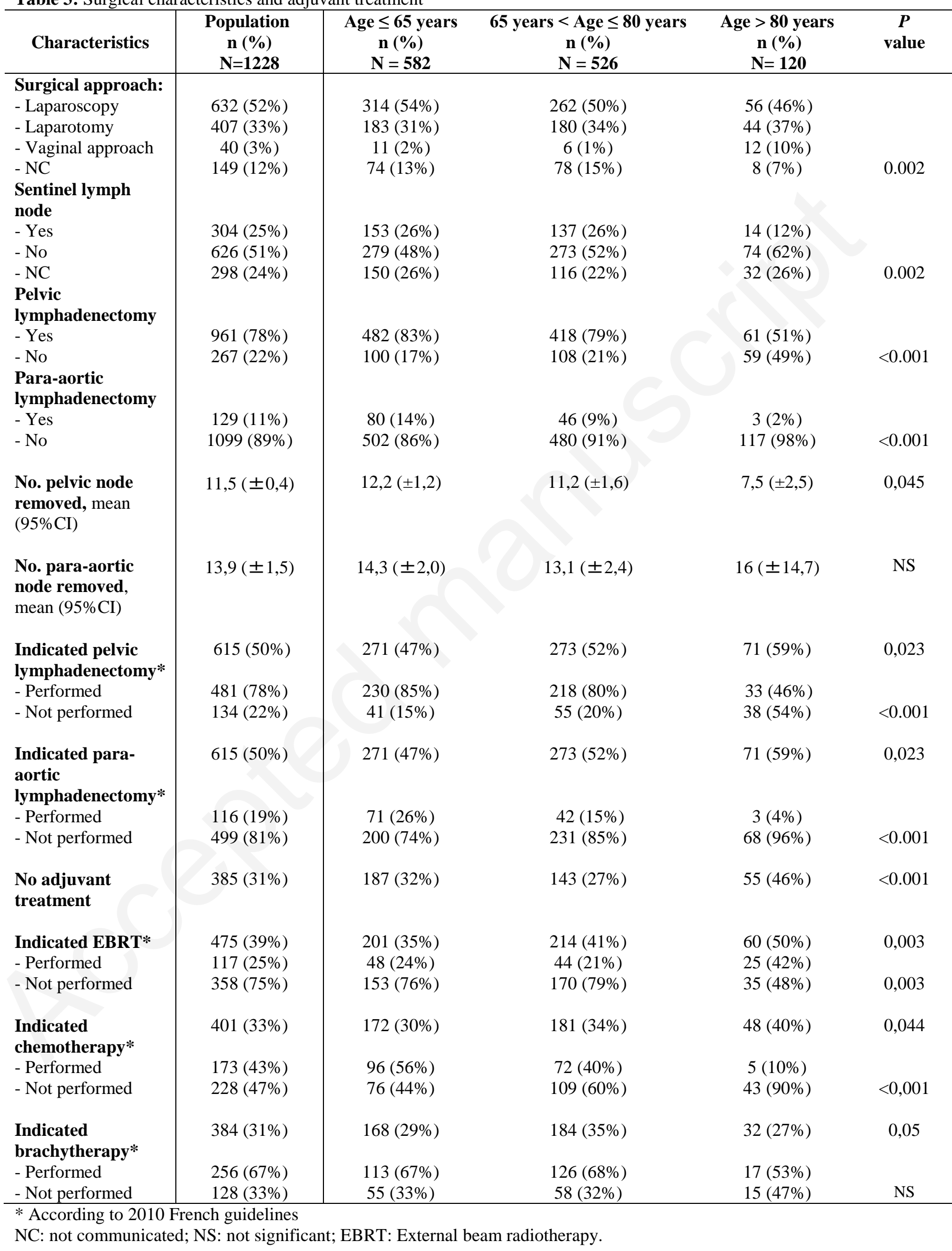


Table 4: Three-year disease-free survival, cancer-specific survival and overall survival rates (multivariate analysis)

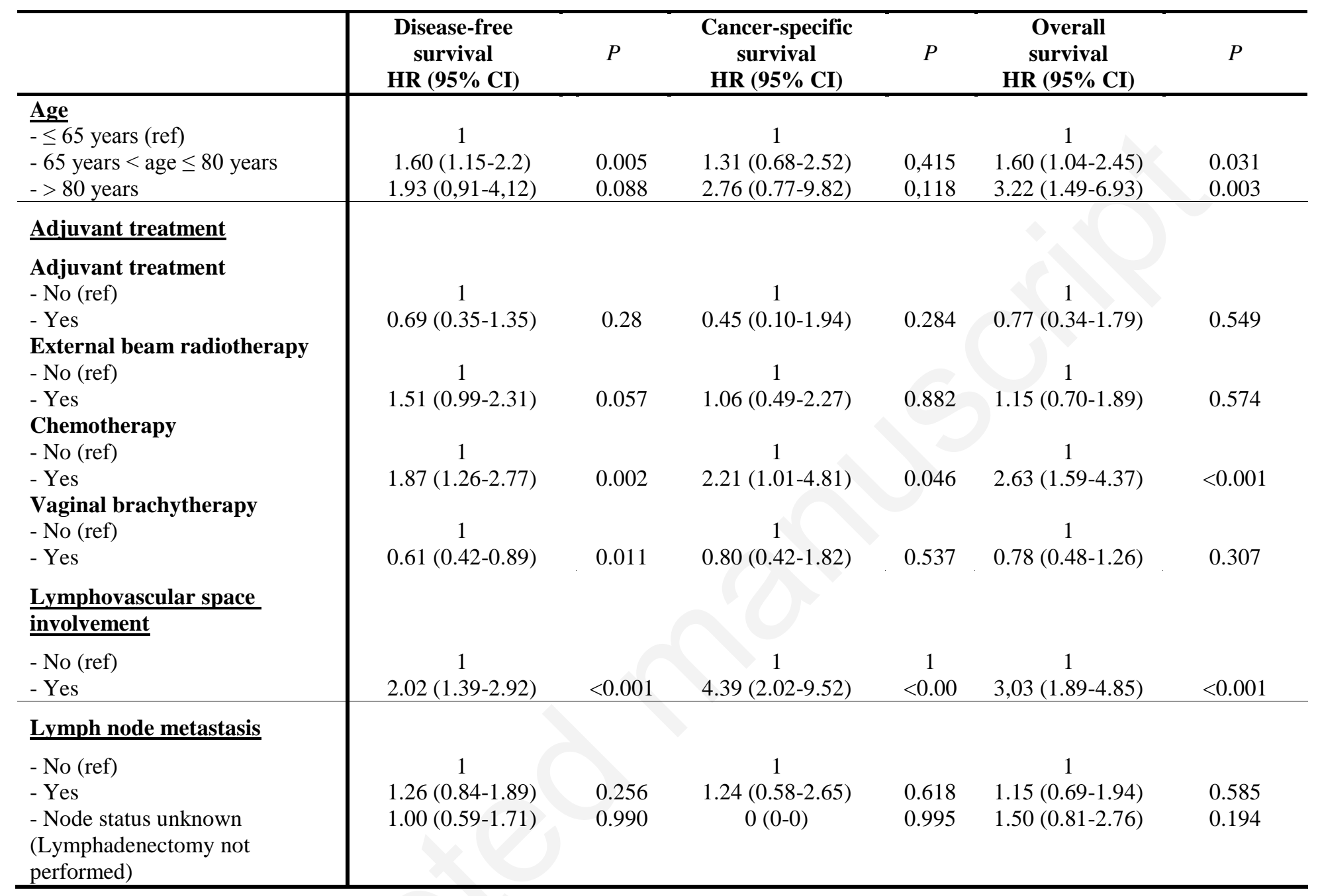

